\title{
EVALUASI STRUKTUR GEDUNG DUAL SYSTEM DENGAN DINDING GESER BERSAYAP C MENGGUNAKAN PUSHOVER ANALYSIS
}

\author{
Albert $^{1}$, Daniel Christianto ${ }^{2}$, dan Hadi Pranata ${ }^{3}$ \\ ${ }^{1}$ Program Studi Sarjana Teknik Sipil, Universitas Tarumanagara, Jl. Letjen S. Parman No.1 Jakarta \\ albert.325160061@stu.untar.ac.id \\ ${ }^{2}$ Program Studi Sarjana Teknik Sipil, Universitas Tarumanagara, Jl. Letjen S. Parman No.1 Jakarta \\ danielc@ft.untar.ac.id \\ ${ }^{3}$ Program Studi Sarjana Teknik Sipil, Universitas Tarumanagara, Jl. Letjen S. Parman No.1 Jakarta \\ hp.rematha@gmail.com
}

Masuk: 03-07-2020, revisi: 09-07-2020, diterima untuk diterbitkan: 04-08-2020

\begin{abstract}
Although elastic analysis gives a good indication of the elastic capacity and behavior of a building, but the elastic method can't predict when the first yield will occur, and the failure mechanism and account for redistribution of member forces when the plastic hinges progressively formed. The use of inelastic procedure for evaluation is an attempt made by engineer in the past days to better understand how the structure will behave when subjected to strong earthquake, assuming the elastic capacity of the structure will be exceeded. In this research the pushover analysis was done using the modelling criteria of FEMA 356. The modeling of C-flanged shear was done using line element with the equivalent strength and stiffness properties. Target displacement was calculated using the displacement coefficient method of FEMA 356. Based on the analysis the triangular load pattern resulted in larger target displacement than the uniform load. But the uniform load pattern gives larger seismic response than the triangular load pattern. The uniform load pattern resulted in Life Safety performance level, while the triangular load pattern resulted in Immediate Occupancy, based on the two load patterns used the structure resulted in Life Safety performance level.
\end{abstract}

Keywords: pushover analysis; shear wall; fema 356

\begin{abstract}
ABSTRAK
Walaupun analisis elastik memberikan indikasi yang baik mengenai kapasitas dan perilaku elastik dari suatu gedung, tetapi metode elastik tidak dapat memperkirakan kapan pelelehan pertama terjadi, serta mekanisme kegagalan apa yang mungkin terjadi pada bangunan tersebut, dan memperkirakan redistribusi dari gaya- gaya dalam ketika pembentukan sendi plastis secara progresif terjadi. Fungsi dari analisis inelastik, sebagai prosedur untuk mengevaluasi bangunan, yang merupakan usaha dari insinyur-insinyur terdahulu memahami bagaimana struktur akan berperilaku apabila dikenai gempa kuat, dimana diasumsikan bahwa kapasitas elastik gedung telah terlampaui. Dalam penelitian ini dilakukan pushover analysis menggunakan kriteria pemodelan berdasarkan FEMA 356. Pemodelan dari dinding geser bersayap C dilakukan menggunakan line element dengan kekuatan dan kekakuan yang ekivalen. Target perpindahan dianalisis menggunakan metode coefficient of displacement dari FEMA 356. Berdasarkan analisis yang dilakukan didapat bahwa pembebanan segitiga lebih besar dibandingkan pembebanan merata. Namun, respons seismik yang didapat akibat beban merata, lebih besar dibandingkan beban segitiga. Pembebanan merata menghasilkan tingkatan kinerja Life Safety, sedangkan pembebanan segitiga menghasilkan tingkatan kinerja Immadiate Occupancy, berdasarkan kedua pembebanan tersebut didapat kinerja dari struktur tersebut adalah Life Safety.
\end{abstract}

Kata kunci: pushover analysis; dinding geser; fema 356

\section{PENDAHULUAN}

Walaupun analisis elastik memberikan indikasi yang baik mengenai kapasitas dan perilaku elastik dari suatu gedung, tetapi metode elastik tidak dapat memperkirakan kapan pelelehan pertama terjadi, serta mekanisme kegagalan apa yang mungkin terjadi pada bangunan tersebut, dan memperkirakan redistribusi dari gaya- gaya dalam ketika pembentukan sendi plastis secara progresif terjadi. Fungsi dari analisis inelastik, sebagai prosedur untuk mengevaluasi bangunan, yang merupakan usaha dari insinyur-insinyur terdahulu memahami bagaimana 
struktur akan berperilaku apabila dikenai gempa kuat, dimana diasumsikan bahwa kapasitas elastik gedung telah terlampaui.

Prosedur pushover analysis, dapat dilihat sebagai suatu metode yang memperhitungkan redistribusi dari gayagaya dalam yang terjadi pada struktur yang dikenakan gaya inersia gempa yang sudah tidak dapat lagi ditahan oleh perilaku elastik dari bangunan tersebut. Pushover analysis mulai populer digunakan dalam proses evaluasi dari struktur gedung sejak tahun 1996-1997, sejak diterbitkannya ATC-40, dan FEMA 273\&274. Pushover analysis, seperti namanya adalah proses mendorong ( $p u s h)$ suatu struktur secara horizontal, dengan suatu pola pembebanan tertentu, secara bertahap, hingga struktur tersebut mencapai limit state-nya (ATC-40, 1996).

Pushover analysis diharapkan dapat memberikan beberapa informasi mengenai kerakteristik respons struktur yang tidak dapat diperoleh dari analisis elastik statik, maupun dinamis. Berikut adalah beberapa kerakteristik respon struktur tersebut (Krawinkler \& Seneviratna, 1998):

- Perkiraan force demand yang realistik pada elemen dengan tipe keruntuhan yang getas, seperti axial force demand pada kolom dan sambungan bracing, moment demand pada hubungan balok kolom, shear force demand pada balok sprandel, dll.

- Perkiraan deformation demand pada elemen yang harus berdeformasi secara inelastik untuk mendisipasi energi pada struktur akibat terjadinya gempa bumi.

- Dampak dari penurunan kekuatan dari suatu elemen terhadap perilaku dari sistem struktur.

- Identifikasi daerah-daerah kritis dimana deformation demand sangat tinggi, sehingga perlu menjadi fokus untuk dilakukan pendetailan khusus.

- Identifikasi ketidak-berlanjutan kekuatan (strength discontinuity) yang dapat menyebabkan perubahan karakteristik dinamis struktur pada dearah inelastik.

- Memperkirakan simpangan antar tingkat yang dapat digunakan untuk mengontrol kerusakan dan mengevaluasi efek P-delta

- Memastikan bahwa beban dapat disalurkan dengan baik hingga ke fondasi, bahkan ketika struktur telah memasuki daerah inelastik.

\section{Pushover analysis}

Pushover analysis, seperti namanya adalah proses mendorong (push) suatu struktur secara horizontal, dengan suatu pola pembebanan tertentu, secara bertahap, hingga struktur tersebut mencapai limit state-nya (ATC-40, 1996). Pushover analisis dapa dianalogikan menggunakan ilustrasi pada Gambar 1, dimana ada sebuah pembebanan horizontal yang mendorong (menarik) struktur hingga limit state struktur tersebut tercapai. Tujuan dari pushover analysis adalah untuk mengevaluasi performa dari suatu sistem struktur dengan memperkirakan strength demand dan deformation demand akibat gempa rencana dengan menggunakan analisis inelastik, dan membandingkan demand ini dengan kapasitas yang tersedia (Krawinkler \& Seneviratna, 1998)

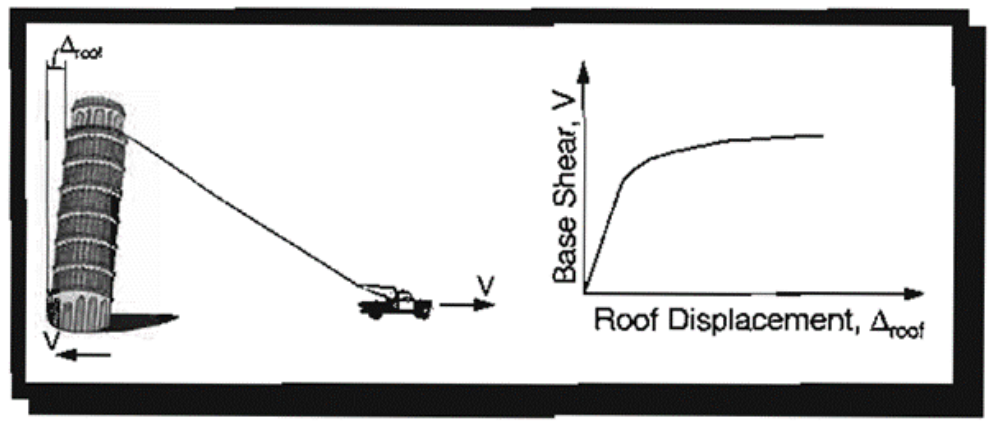

Gambar 1. Analogi dari pushover analysis (Sumber: ATC 40,1996)

\section{Displacement coefficient method (FEMA 356)}

Dalam metode ini dilakukan pendekatan dengan memodifikasi respon linier elastik dari suatu struktur SDOF ekivalen, dengan mengalikannya dengan koefisien $\mathrm{C}$, hingga $\mathrm{C} 3$ untuk mendapatkan perkiraan dari perpindahan struktur maksimum (target displacement).

Perpindahan rencana ditetapkan berdasarkan persamaan berikut: 


$$
\delta_{t}=C_{0} C_{1} C_{2} C_{3} S_{a} \frac{T_{e}^{2}}{4 \pi^{2}} g
$$

dengan $C_{0}=$ koefisien faktor bentuk, untuk merubah perpindahan spectral dari struktur sdof ekivalen menjadi perpindahan atap,$C_{1}=$ faktor modifikasi untuk menghubungkan perpindaha inelastik maksimum dengan respons elastik linier, $C_{2}=$ koefisien untuk memperhitungkan efek pinching dari hubungan beban deformasi akibat degradasi kekakuan dan kekuatan, $C_{3}=$ koefisien untuk memperhitungkan pembesaran lateral akibat adanya efek Pdelta, , Te=perioda fundamental efektif bangunan, $T_{i} \sqrt{\frac{K_{i}}{K_{e}}}, \mathrm{Sa}=$ percepatan spektrum pada perioda efektif bangunan, $\mathrm{g}=$ percepatan gravitasi.

\section{Kinerja struktur}

Setelah analisis pushover dilakukan, dan telah didapat perpindahan rencana (displacement coefficient method), selanjutnya dilakukan pengecekan kinerja dari struktur tersebut. Tingkatan kinerja suatu bangunan didapat dengan membandingkan respon struktur dan deformasi dari masing-masing elemen terhadap nilai batas yang telah ditentukan untuk bangunan. Nilai batas yang ditentukan berdasarkan FEMA 356, dapat dilihat pada Tabel 1 dibawah ini.

Tabel 1. Tingkat kinerja struktur

\begin{tabular}{clll}
\hline \multirow{2}{*}{ Elemen } & \multicolumn{3}{c}{ Tingkatan Kinerja } \\
\cline { 2 - 4 } & \multicolumn{1}{c}{ Collapse Prevention } & \multicolumn{1}{c}{ Life Safety } & \multicolumn{1}{c}{ Immadiate Occupancy } \\
\hline Portal Beton & $4 \%$ simpangan & $2 \%$ simpangan & $1 \%$ simpangan sementara, \\
& sementara dan & sementara, 1\% & simpangan permanen \\
& permanen & simpangan permanen & diabaikan \\
\multirow{3}{*}{ Dinding Beton } & $2 \%$ simpangan & $1 \%$ sementara, 0.5 \% & $0.5 \%$ simpangan \\
& sementara dan & simpangan permanen & sementara, simpangan \\
& permanen & & permanen diabaikan \\
\hline
\end{tabular}

(Sumber: FEMA 356, 2000)

\section{METODE PENELITIAN}

Gedung yang akan dianalisis merupakan gedung dengan ketinggian 23 lantai (21 lantai + mezzanine dan atap) yang diperuntukan untuk fasilitas pendidikan, kantor dan gedung pertemuan, yang dapat dilihat pada Gambar 2. Bangunan yang akan dievaluasi berlokasi di daerah Jakarta Barat, dan diasumsikan berada diatas tanah lunak.

Pemodelan dan analisis dalam penelitian ini dilakukan dengan menggunakan program ETABS. Struktur dimodelkan sebagai struktur 3D, dengan sistem struktur balok, kolom, dan dinding geser. Perhitungan beban hidup bertasarkan SNI 1727:2013 "Beban Minimum untuk Perancangan Bangunan Gedung dan Struktur Lain". Perhitungan besarnya gaya gempa rencana berdasarkan spektrum desain SNI 1726:2012 "Tata Cara Perencanaan Ketahanan Gempa untuk Struktur Bangunan Gedung dan Non Gedung”
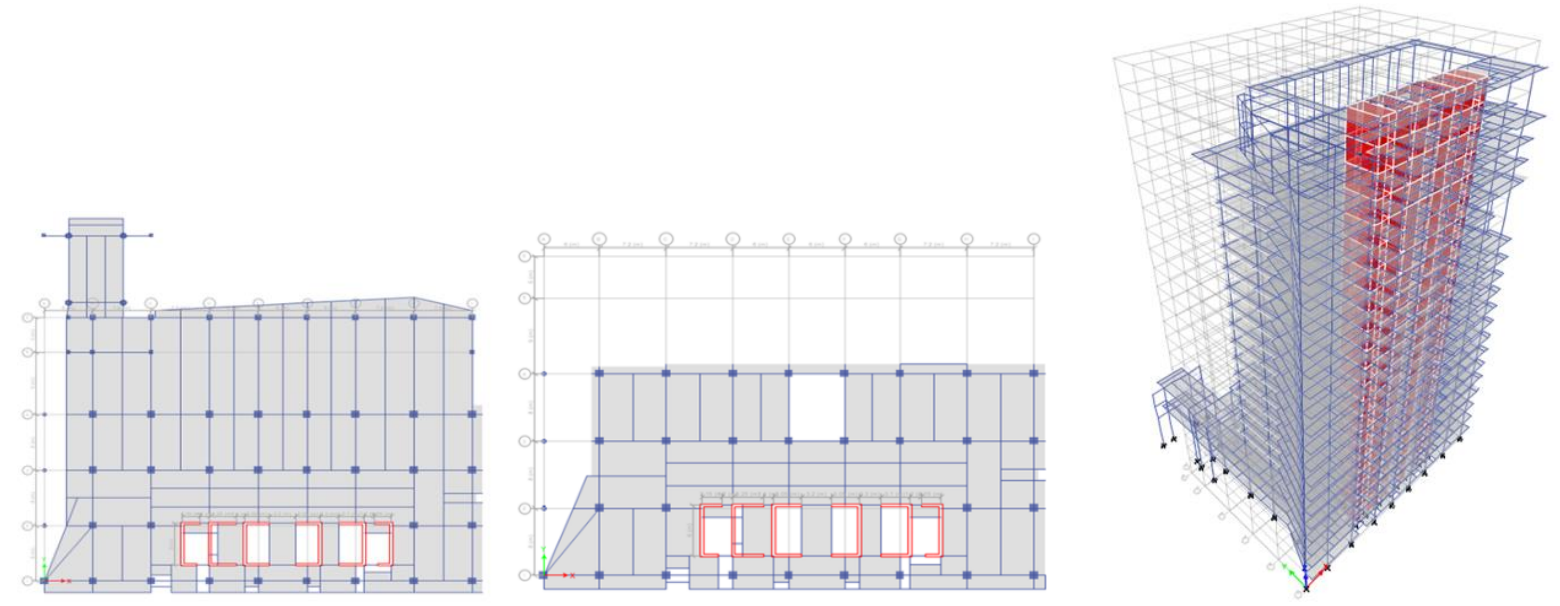

Gambar 2. Denah dan tampak 3D gedung 


\section{HASIL DAN PEMBAHASAN}

\section{Pemodelan dinding geser sebagai line element}

Dinding geser digunakan pada gedung merupakan dinding geser berbentuk C, dengan tebal badan 400mm, dan tebal sayap 300mm. dinding geser dimodelkan menggunakan line element dengan kekakuan dan kekuatan penampang yang ekivalen. Karena dimodelkan sebagai line element, nodal pada masing-masing ujung elemen, harus dihubungkan dengan nodal dari element lain menggunakan rigid link element (CSI, 2013). Pemodelan dari dinding geser menggunakan line element dapat dilihat pada Gambar 3 dan Gambar 4.

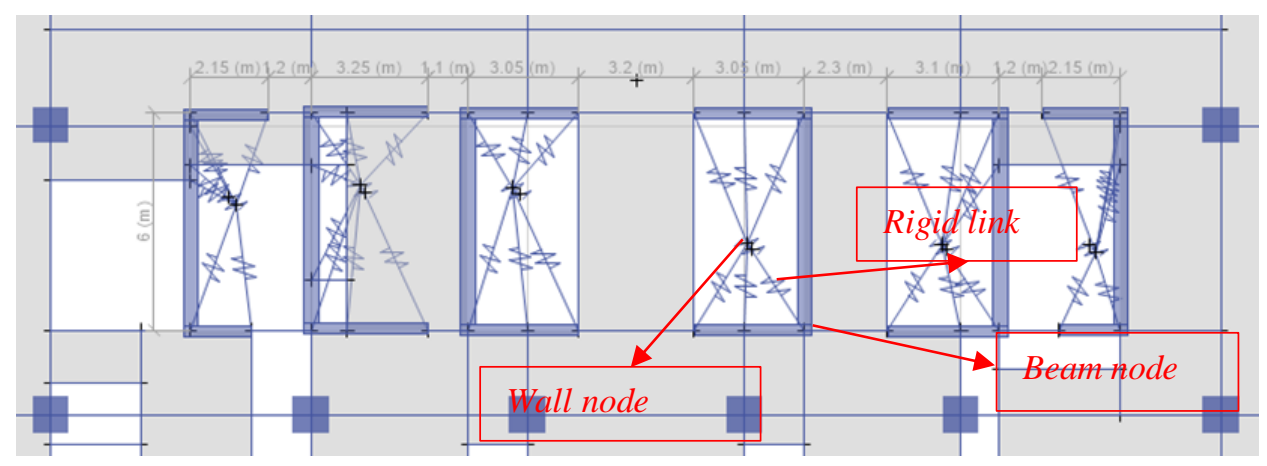

Gambar 3. Pemodelan dinding geser dengan line element

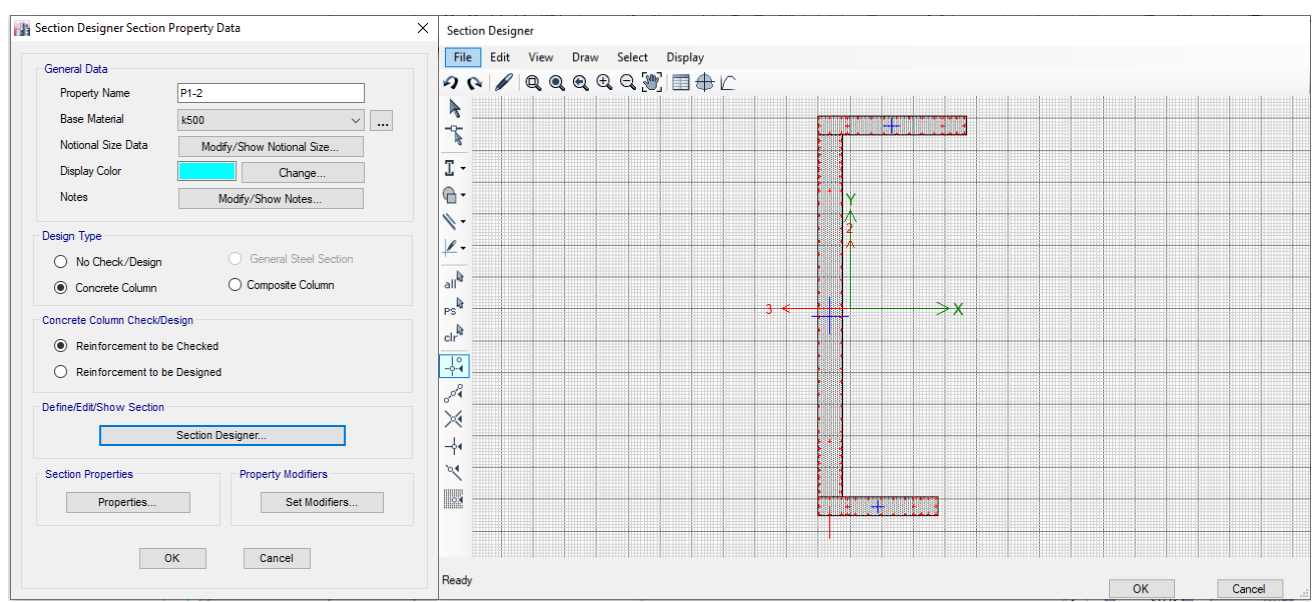

Gambar 4. Pemodelan elemen dinding geser

\section{Penentuan load pattern}

Berdasarkan FEMA 356, pasal 3.3.3.2.3, pushover analysis dilakukan untuk masing-masing 1 dari dua grup dibawah ini.

Grup pertama:

1. Pola pembebanan segitiga

2. Pola pembebanan mode pertama

3. Pola pembebanan berdasarkan kombinasi modal hingga total partisipasi massa mencapai 90 persen

Grup kedua:

1. Pola pembebanan Adaptive

2. Pola pembebanan merata

Dalam penelitian ini dipilih pola pembebanan segitiga dan merata untuk analisis pushover. Pembebanan lateral serta distribusi percepatan tingkat yang digunakan dalam pushover analysis dapat dilihat pada Tabel 2 dan Gambar 5 dibawah ini. 
Tabel 2. Pembebanan lateral

\begin{tabular}{|c|c|c|c|c|}
\hline & \multicolumn{2}{|c|}{ Pembebanan Segitiga } & \multicolumn{2}{|c|}{ Pembebanan Merata } \\
\hline & $\begin{array}{c}\text { Fx } \\
(\mathrm{kg})\end{array}$ & $\begin{array}{c}\text { Fy } \\
\text { (kg) }\end{array}$ & $\begin{array}{c}\mathrm{Fx} \\
(\mathrm{kg})\end{array}$ & $\begin{array}{c}\text { Fy } \\
(\mathrm{kg})\end{array}$ \\
\hline lt atap & 522002,88 & 415828,5 & 244990,66 & 195160 \\
\hline lt mezanine & 191364,67 & 152441,5 & 94039,318 & 74911,9 \\
\hline lt21 & 973190,29 & 775245,2 & 501856,31 & 399779,7 \\
\hline lt20 & 864800,07 & 688901,4 & 469128,3 & 373708,5 \\
\hline lt19 & 819875,39 & 653114,3 & 469128,3 & 373708,5 \\
\hline lt18 & 784422,18 & 624872,2 & 474862 & 378276 \\
\hline lt17 & 714698,32 & 569330 & 459278,43 & 365862,1 \\
\hline lt16 & 680974,04 & 542465,2 & 466302,09 & 371457,1 \\
\hline lt15 & 663669,31 & 528680,2 & 486343,95 & 387422,5 \\
\hline lt14 & 612812,57 & 488167,7 & 482968,09 & 384733,3 \\
\hline lt13 & 527646,08 & 420323,9 & 449793,61 & 358306,4 \\
\hline lt12 & 482565,21 & 384412,4 & 447929,98 & 356821,9 \\
\hline lt11 & 446510,44 & 355691,1 & 454898,39 & 362372,9 \\
\hline lt10 & 412463,71 & 328569,4 & 465640,41 & 370930 \\
\hline lt9 & 415168,79 & 330724,2 & 525505,66 & 418618,8 \\
\hline lt8 & 364845,3 & 290636,5 & 525505,66 & 418618,8 \\
\hline lt7 & 316222,3 & 251903,3 & 528346,86 & 420882,1 \\
\hline lt6 & 274877,83 & 218968,2 & 546747,82 & 435540,3 \\
\hline $1 \mathrm{t} 5$ & 312105,8 & 248624,1 & 766866,13 & 610887 \\
\hline $\operatorname{lt} 4$ & 157048,84 & 125105,4 & 504612,53 & 401975,3 \\
\hline 1t3 & 162201,05 & 129209,7 & 752796,86 & 599679,4 \\
\hline lt 2 & 79129,781 & 63034,93 & 661053,48 & 526596,5 \\
\hline
\end{tabular}

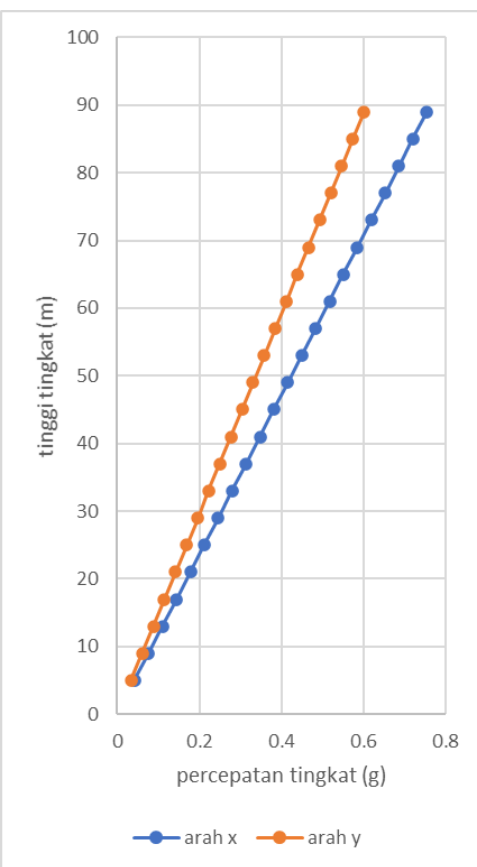

(a)

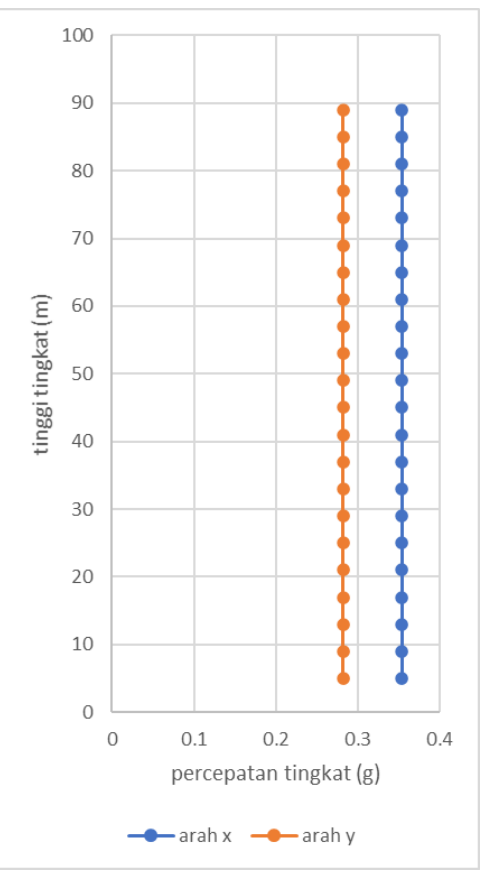

(b)

Gambar 5. Percepatan tingkat (a) distribusi beban segitiga, (b) distribusi beban merata 
Setelah pushover analysis dengan pola pembebanan di atas dilakukan, didapat kurva kapasitas. Kurva kapasitas diperoleh berdasarkan hubungan antara gaya geser dasar (base shear) yang terjadi dengan defleksi dari pusat massa atap sebagai hasil dari Analisis pushover. Kurva kapasitas dari gedung yang dibahas dalam penelitian ini dapat dilihat pada Gambar 6 dan Gambar 7 dibawah ini.

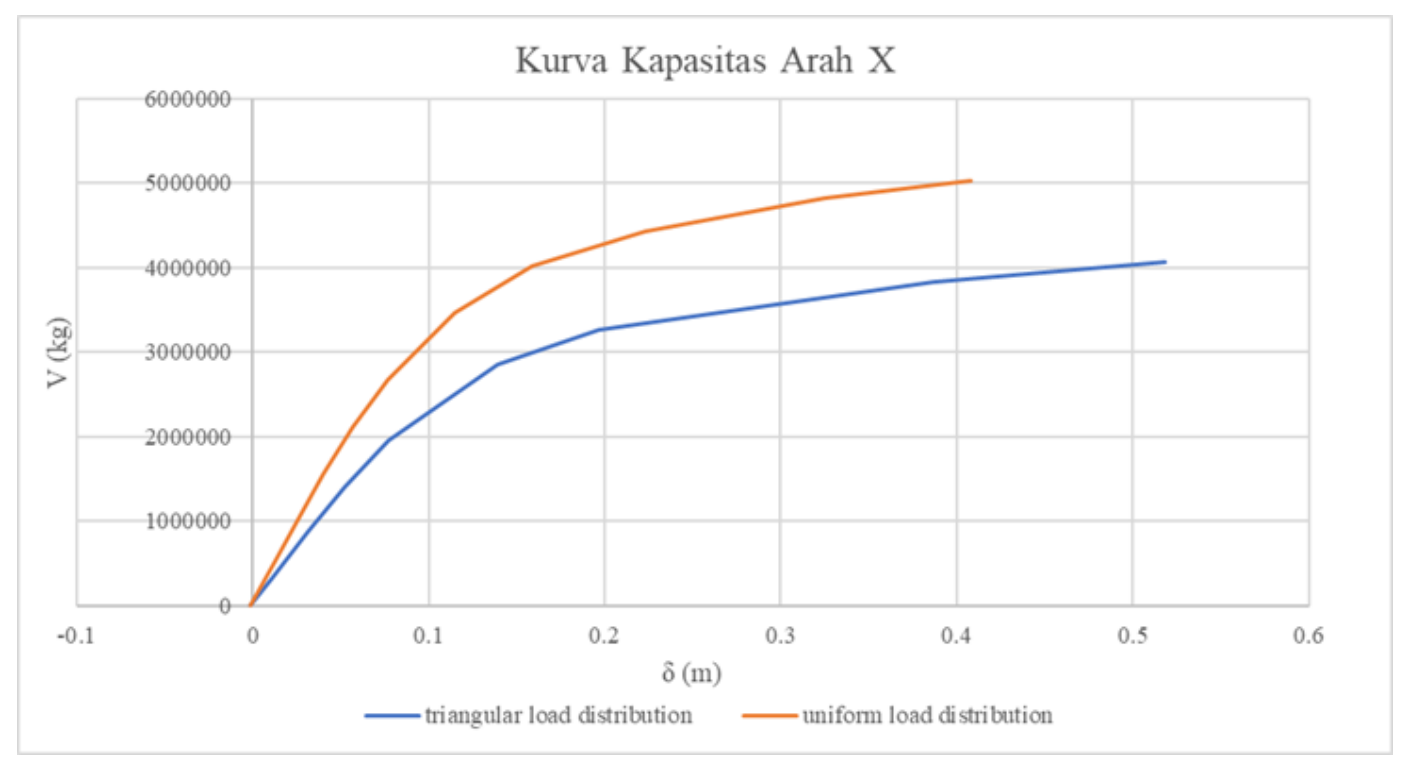

Gambar 6. Kurva kapasitas arah X akibat pembebanan segitiga dan merata

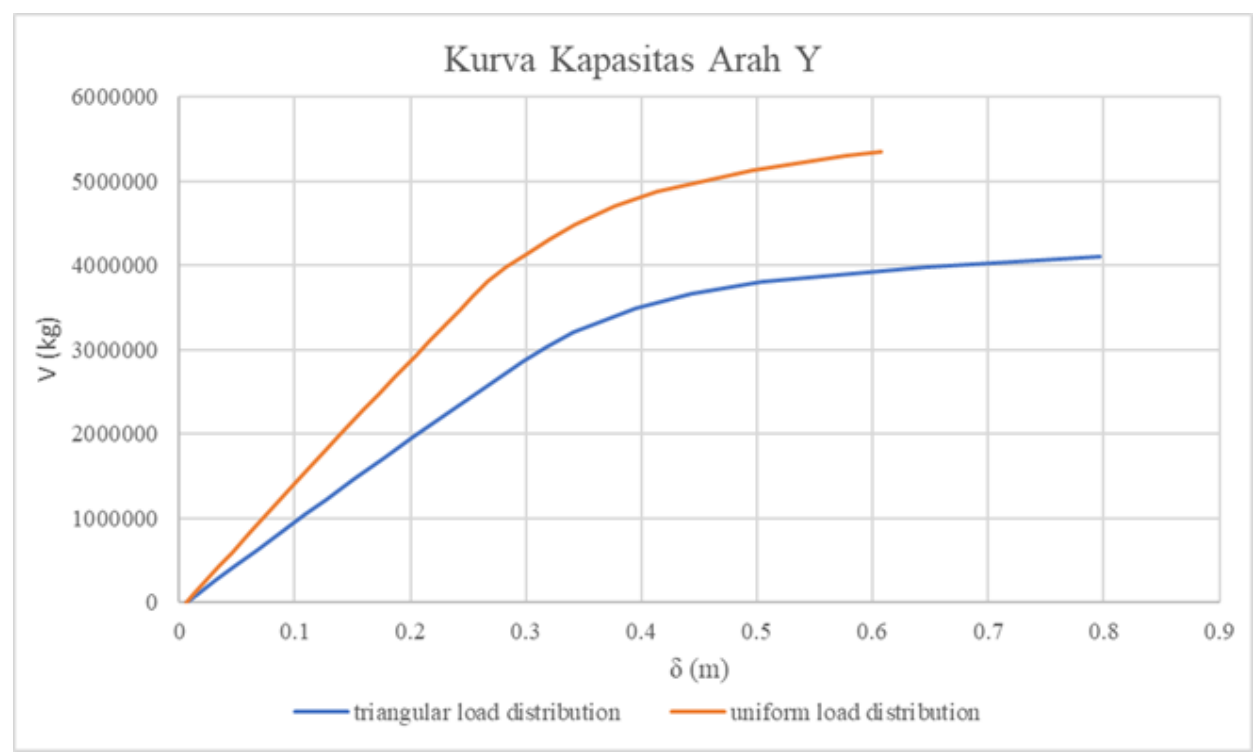

Gambar 7. Kurva kapasitas arah X akibat pembebanan segitiga dan merata

\section{Menentukan perpindahan rencana}

Setelah pushover analysis dilakukan untuk masing-masing arah, selanjutnya dilakukan analisis untuk menentukan perpindahan rencana. Perpindahan Rencana dianalisis berdasarakan metode coefficient of displacement (FEMA 356). Gambar 8 sampai Gambar 11 dan Tabel 3 berikut menampilkan perpindahan rencana untuk masing-masing arah pembebanan. 
Tabel 3. Perpindahan rencana

\begin{tabular}{lcccc}
\hline Model & $\begin{array}{c}\text { Arah X } \\
\text { Triangular }\end{array}$ & $\begin{array}{c}\text { Arah X } \\
\text { Uniform }\end{array}$ & $\begin{array}{c}\text { Arah Y } \\
\text { Triangular }\end{array}$ & $\begin{array}{c}\text { Arah y } \\
\text { Uniform }\end{array}$ \\
\hline $\mathrm{Ki}(\mathrm{kg} / \mathrm{m})$ & 26245982,06 & 37462097,87 & 10221725,00 & 15245470,53 \\
$\mathrm{Ti}(\mathrm{det})$ & 1,577 & 1,577 & 2,99 & 2,99 \\
$\mathrm{Ke}(\mathrm{kg} / \mathrm{m})$ & 25806366,17 & 36952018,36 & 9977864,49 & 14883958,28 \\
$\alpha \mathrm{Ke}(\mathrm{kg} / \mathrm{m})$ & 4747227,92 & 7307949,48 & 2860076,96 & 4443005,38 \\
$\mathrm{Te}(\mathrm{det})$ & 1,5904 & 1,5878 & 3,0263 & 3,0261 \\
$\mathrm{Sa}(\mathrm{g})$ & 0,3508 & 0,3513 & 0,1843 & 0,1843 \\
$\mathrm{Vy}(\mathrm{kg})$ & 2650000 & 3300000 & 3250000 & 4200000 \\
$\mathrm{~W}(\mathrm{~kg})$ & 30469949,33 & 30469949,33 & 30469949,33 & 30469949,33 \\
$\mathrm{R}$ & 4,0332 & 3,2439 & 1,7282 & 1,3374 \\
$\mathrm{C} 0$ & 1,3 & 1,2 & 1,3 & 1,2 \\
$\mathrm{C} 1$ & 1 & 1 & 1 & 1 \\
$\mathrm{C} 2$ & 1 & 1 & 1 & 1 \\
$\mathrm{C} 3$ & 1 & 1 & 1 & 1 \\
St $(\mathrm{m})$ & 0,2866 & 0,2641 & 0,5454 & 0,5034 \\
\hline
\end{tabular}

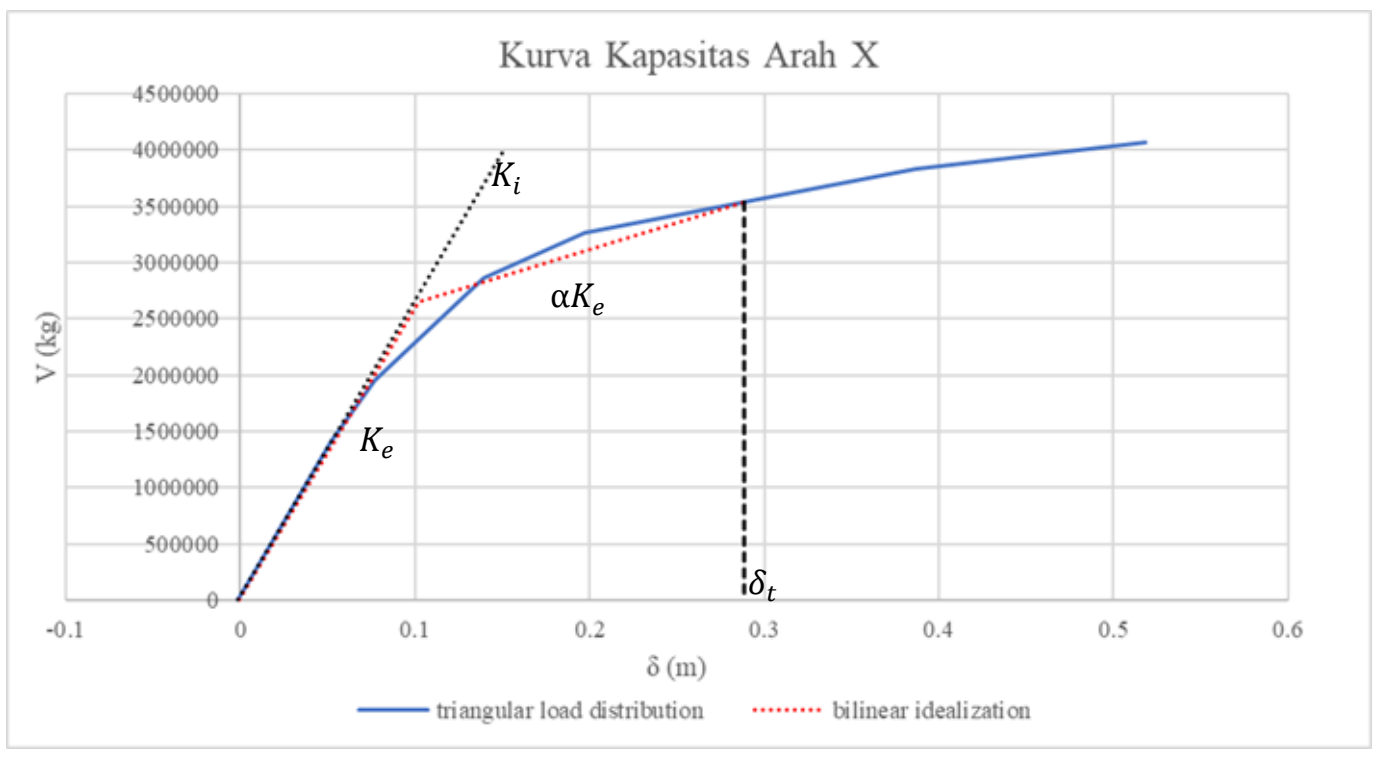

Gambar 8. Kurva kapasitas arah X dengan pembebenan segitiga dan idealisasi biliniernya 


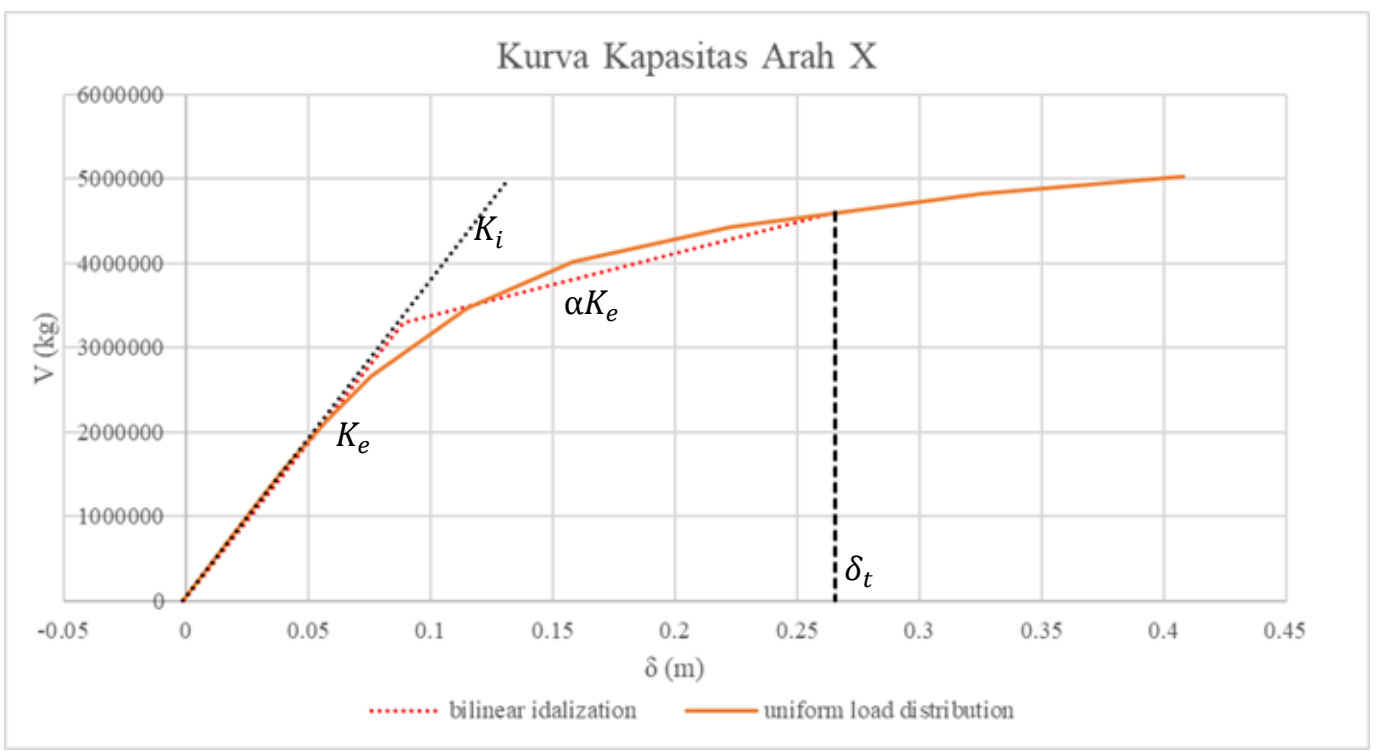

Gambar 9. Kurva kapasitas arah X dengan pembebanan merata dan idealisasi biliniernya

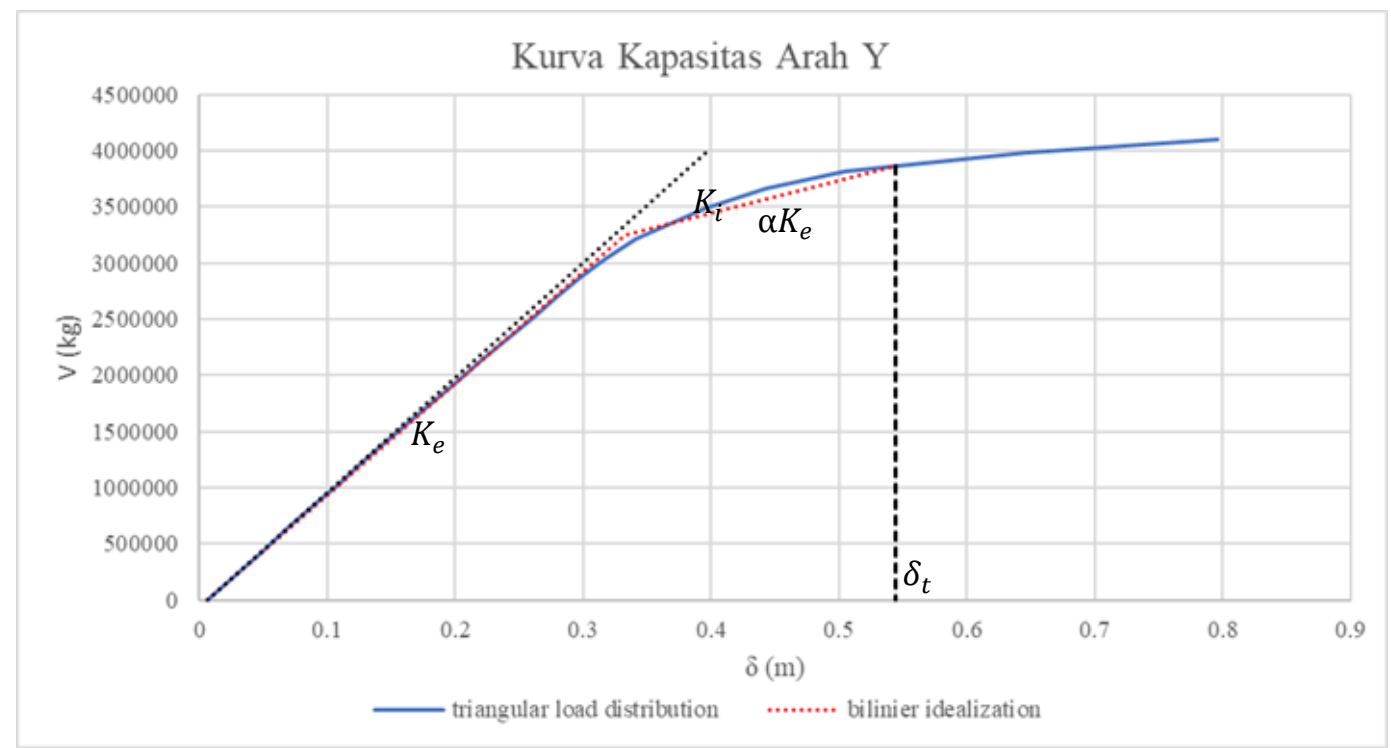

Gambar 10. Kurva kapasitas arah Y dengan pembebanan segitiga dan idealisasi biliniernya 


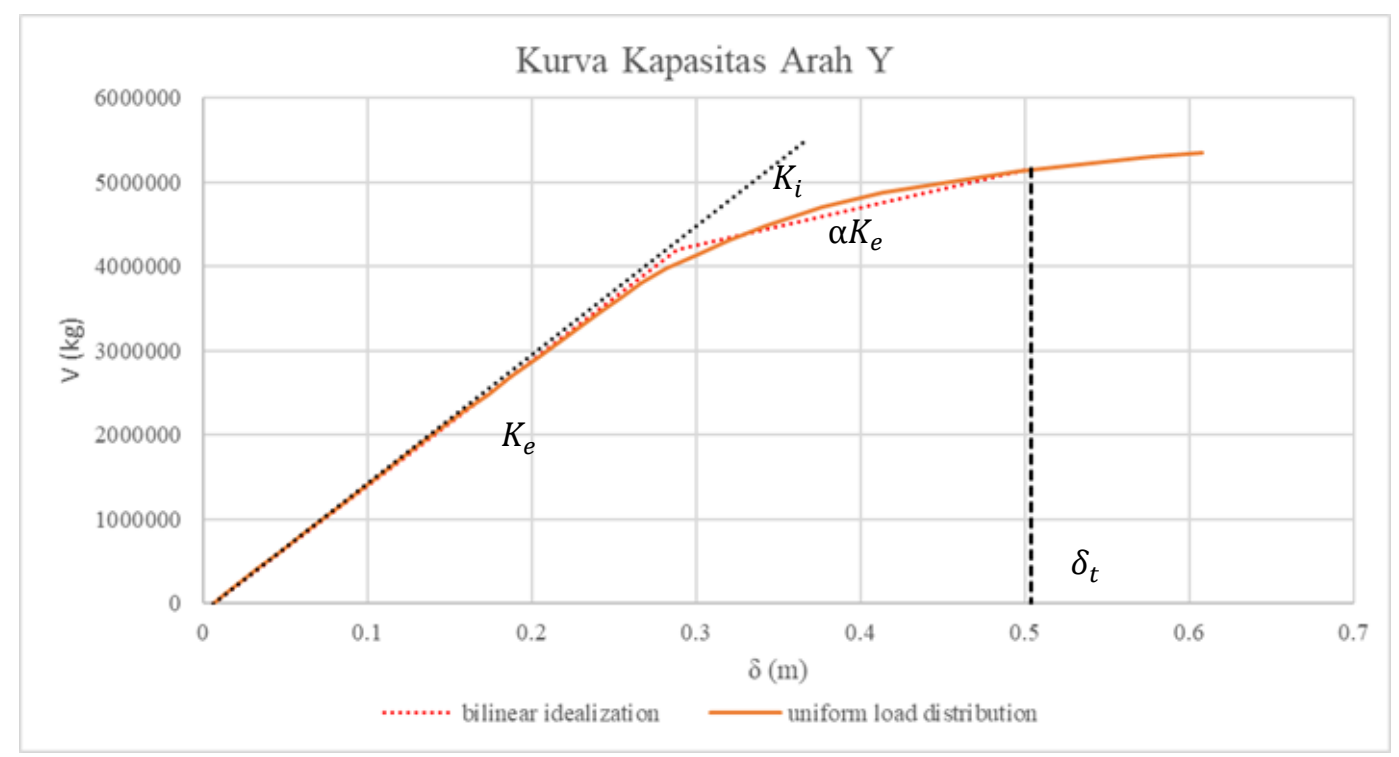

Gambar 11. Kurva kapasitas arah Y dengan pembebanan merata dan idealisasi biliniernya

\section{Respons seismik pada saat target displacement}

Setelah didapat struktur mencapai target displacement, dilakukan pengecekan nilai respons seismik yang terjadi, sehingga diperoleh perkiraan seismic demand pada saat gempa rencana terjadi. Dalam penelitian ini seismic demand diamati berupa interstory drift, dan rotasi sendi plastis maksimum. Interstory drift, dan rotasi sendi plastis maksimum yang didapat berdasarkan analisis pushover untuk masing-masing arah pembebanan dapat dilihat pada Gambar 12 hingga Gambar 15 berikut ini.

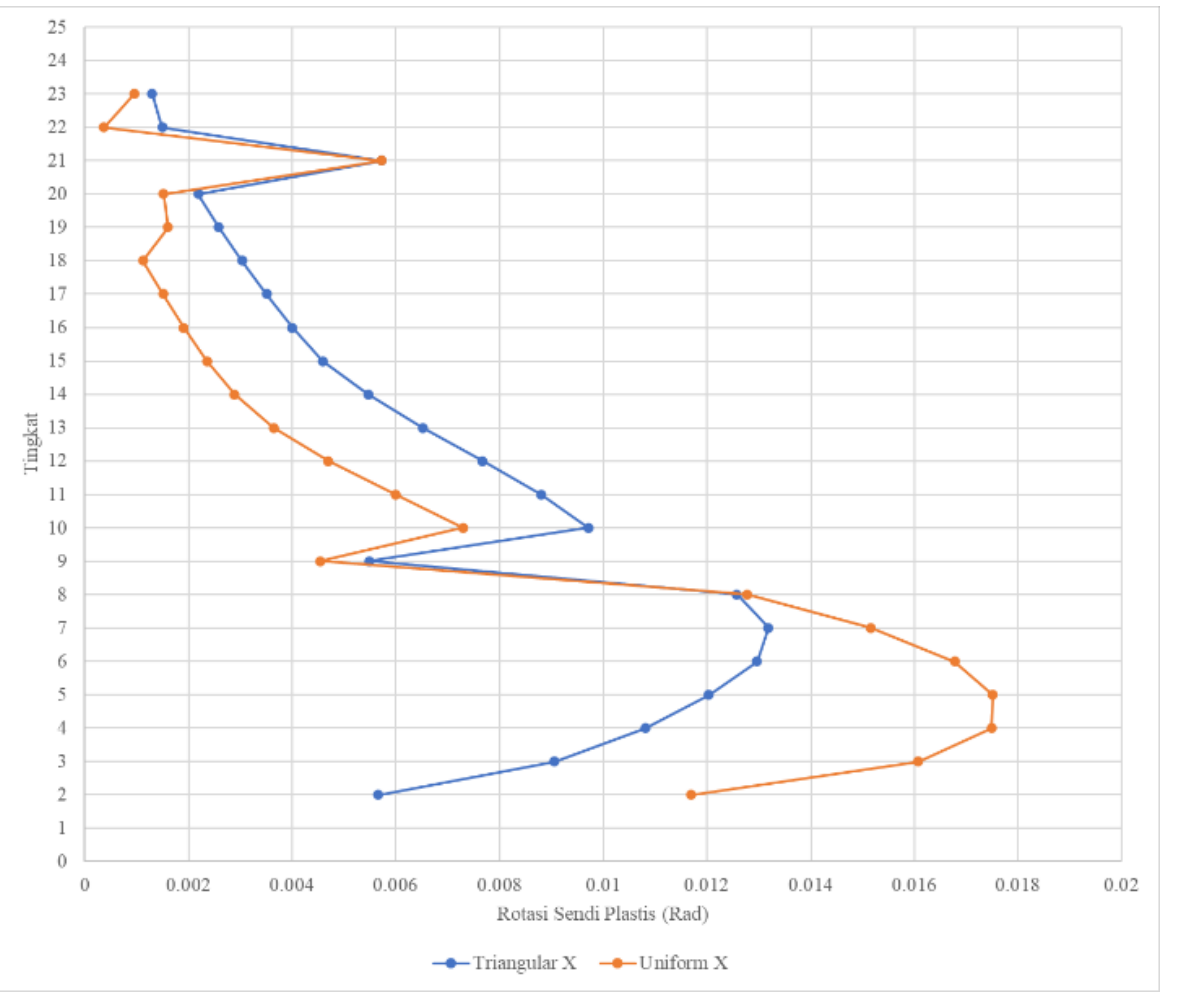

Gambar 12. Rotasi sendi plastis maksimum arah X pada saat perpindahan rencana tercapai 


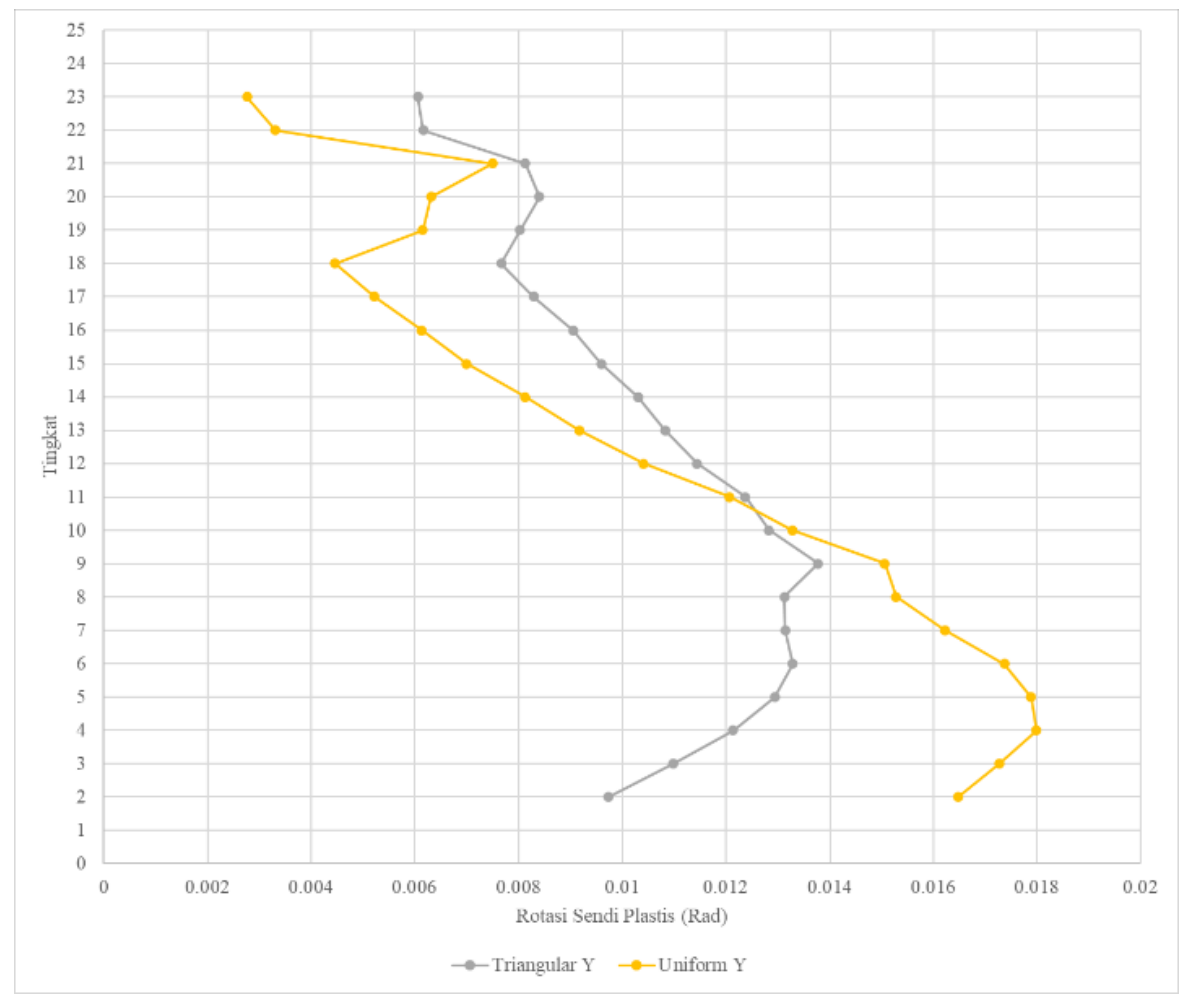

Gambar 13. Rotasi sendi plastis maksimum arah Y pada saat perpindahan rencana tercapai

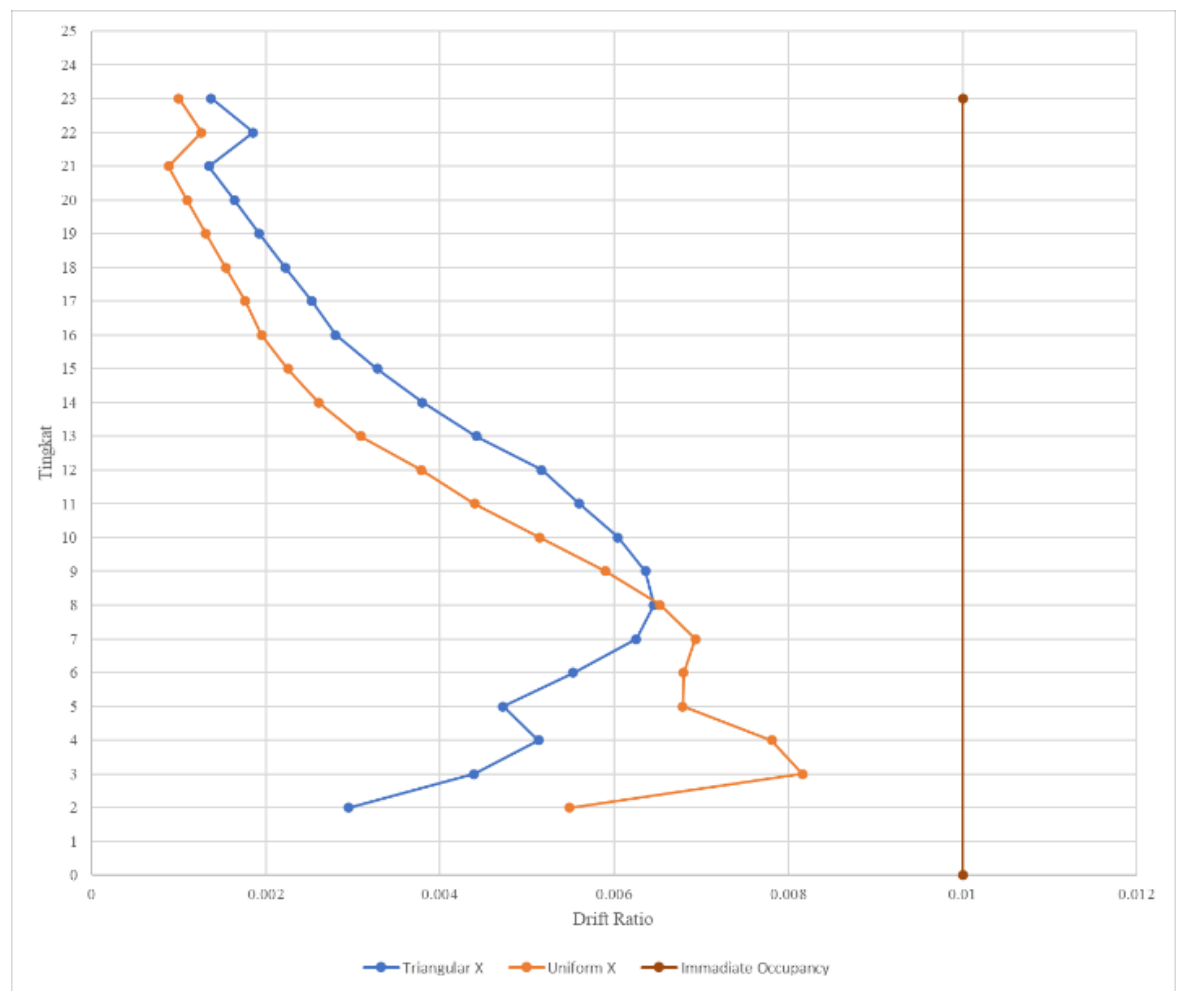

Gambar 14. Interstory drift maksimum arah X pada saat perpindahan rencana tercapai 


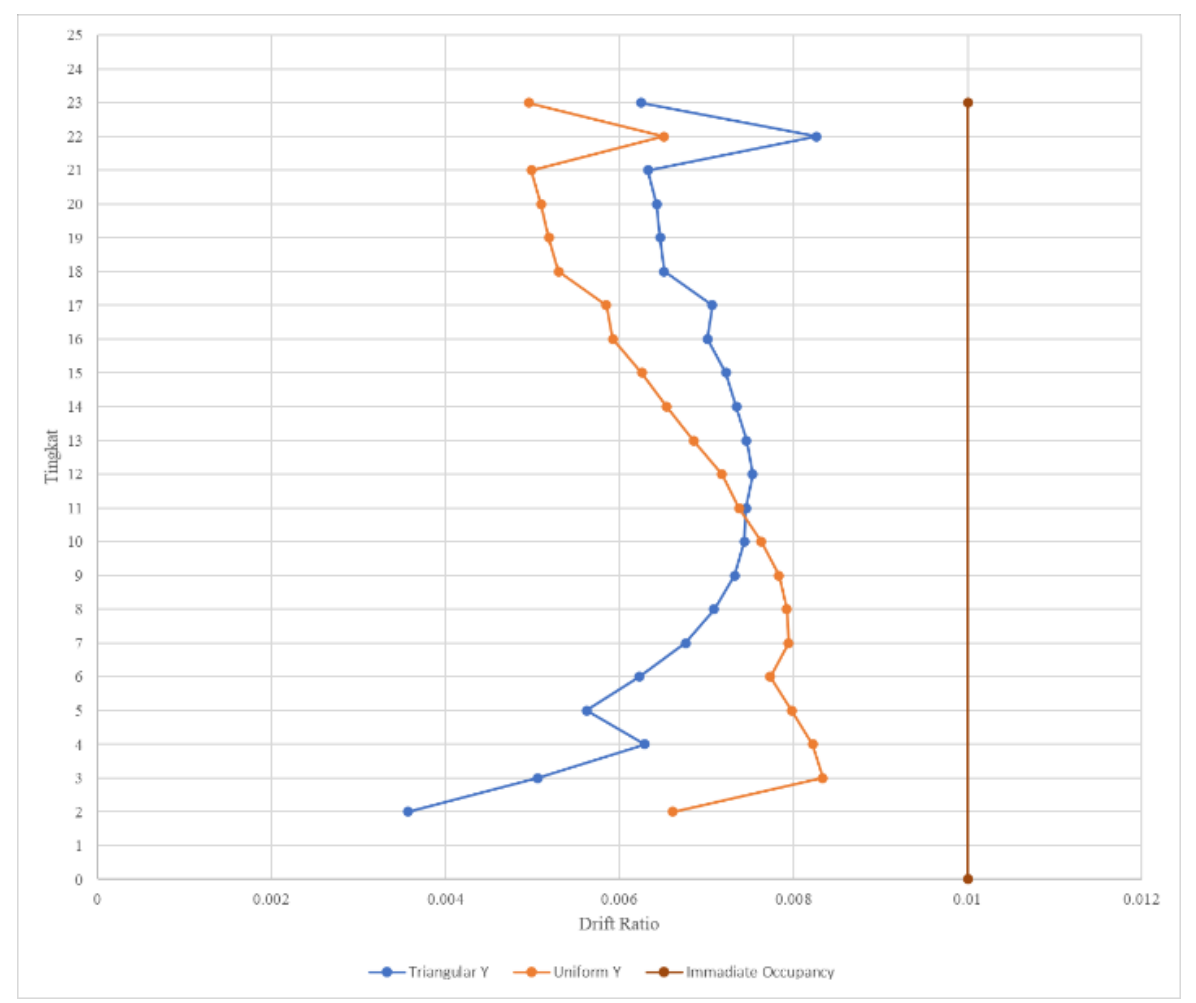

Gambar 15. Interstory drift maksimum arah Y pada saat perpindahan rencana tercapai

\section{Kriteria kinerja}

Kriteria kinerja didapat dengan membandingkan respons seismik maksimum yang terjadi pada bangunan dengan kriteria penerimaan pada Tabel 1. Tingkatan kinerja yang diperoleh berdasarkan pushover analysis untuk masingmasing arah pembebanna dapat dilihat pada Tabel 5 dan Tabel 6 di bawah ini.

Tabel 4. Kinerja struktur berdasarkan rotasi sendi plastis

\begin{tabular}{cccc}
\hline & Pola Pembebanan & $\begin{array}{c}\text { Rotasi Sendi Plastis } \\
\text { maximum(Radian) }\end{array}$ & Kriteria Kinerja \\
\hline \multirow{2}{*}{ Arah X } & $\begin{array}{c}\text { Triangular Load } \\
\text { Uniform Load }\end{array}$ & 0,0132 & 0,0175 \\
\hline \multirow{2}{*}{ Arah Y } & Triangular Load & 0,0061 & $\begin{array}{c}\text { Life Safety } \\
\text { Life Safety }\end{array}$ \\
& Uniform Load & 0,0187 & $\begin{array}{c}\text { Immadiate } \\
\text { Occupancy } \\
\text { Life Safety }\end{array}$ \\
\hline
\end{tabular}

Tabel 5. Kriteria kinerja berdasarkan simpangan antar tingkat

\begin{tabular}{|c|c|c|c|}
\hline & banan & Maximum Drift Ratio & Kriteria Kinerja \\
\hline \multirow{2}{*}{ Arah X } & Triangular Load & $0,6527 \%$ & $\begin{array}{l}\text { Immadiate } \\
\text { Occupancy }\end{array}$ \\
\hline & Uniform Load & $0,8162 \%$ & $\begin{array}{l}\text { Immadiate } \\
\text { Occupancy }\end{array}$ \\
\hline \multirow{2}{*}{ Arah Y } & Triangular Load & $0,826 \%$ & $\begin{array}{l}\text { Immadiate } \\
\text { Occupancy }\end{array}$ \\
\hline & Uniform Load & $0,834 \%$ & $\begin{array}{l}\text { Immadiate } \\
\text { Occupancy }\end{array}$ \\
\hline
\end{tabular}

\section{KESIMPULAN DAN SARAN}

\section{Kesimpulan}

Berdasarkan analisis yang telah dilakukan, didapat target perpindahan pada 0,2866m akibat beban segitiga arah X, 0,2631 m akibat beban merata arah X, 0,5454 akibat beban segitiga arah Y, dan 0,5034 akibat beban merata arah 
Y. Dapat dilihat, bahwa target perpindahan akibat beban segitiga lebih besar daripada beban merata untuk masingmasing arah pembebanan. Pembebanan merata, menghasilkan respon seismik yang lebih besar dibandingkan beban segitiga, terutama respons seismik pada tingkat-tingkat bawah. Respons seismik terbesar didapat akibat pembebanan merata untuk masing-masing arah pembebanan. Berdasarkan pembebanan segitiga diperoleh tingkatan kinerja Immadiate Occupancy, dan akibat pembebanan merata Life Safety, sehingga, disimpulkan kinerja dari struktur tersebut berada pada tingkatan Life Safety.

\section{Saran}

Perlunya dilakukan evaluasi struktur lebih lanjut menggunakan metode yang menyertakan efek dari mode-mode tinggi, oleh karena efek mode-mode tinggi pada metode pushover berdasarkan FEMA 356 belum disertakan. Karena pola-pola pembebanan yang ada pada FEMA 356 diturunkan berdasarkan mode pertama, sehingga akan menjadi kurang tepat untuk bangunan dengan mode pertama tidak dominan.

\section{DAFTAR PUSTAKA}

ATC-40. Seismic Evaluation and Retrofit of Concrete Buildings. California: Apllied Technology Council, 1996. Badan Standardisasi Nasional. Beban Minimum untuk Perancangan Bangunan Gedung dan Struktur Lain (SNI 1727:2013). Jakarta: BSN, 2013.

Badan Standardisasi Nasional. Tata Cara Perencanaan Ketahanan Gempa untuk Struktur Bangunan Gedung dan non-Gedung (SNI 1726:2012). Jakarta: BSN, 2012.

CSI. Analysis Reference Manual For SAP 2000, ETABS, SAFE, Csi Bridge. Berkeley: Computer and Structures Inc., 2013.

FEMA 356. Prestandard and Commentary for the Seismic Rehabilitation of Buildings. Washington, D. C. : Federal Emergency Management Agency, 2000.

Krawinkler, Helmut dan G. G. P. K. Seneviratna. "Pros and cons of a pushover analysis of seismic performance evaluation." Engineering Structures ,1998: 452-464. 